\begin{tabular}{|l|l|l||}
\hline \multicolumn{2}{|c|}{ PublisherInfo } \\
\hline \hline PublisherName & $:$ & BioMed Central \\
\hline \hline PublisherLocation & $:$ & London \\
\hline \hline PublisherImprintName & $:$ & BioMed Central \\
\hline \hline
\end{tabular}

\title{
Worm reanimation checkpoint
}

\begin{tabular}{|l|l|l||}
\hline \multicolumn{2}{|c|}{ ArticleInfo } \\
\hline \hline ArticleID & $:$ & 4877 \\
\hline \hline ArticleDOI & $:$ & $10.1186 /$ gb-spotlight-20031107-03 \\
\hline \hline ArticleCitationID & $:$ & spotlight-20031107-03 \\
\hline \hline ArticleSequenceNumber & $:$ & 229 \\
\hline \hline ArticleCategory & $:$ & Research news \\
\hline ArticleFirstPage & $:$ & 1 \\
\hline \hline ArticleLastPage & $:$ & 3 \\
\hline \hline & & RegistrationDate : 2003-11-7 \\
\hline ArticleHistory & $:$ & OnlineDate \\
\hline ArticleCopyright & $:$ & BioMed Central Ltd2003-11-7 \\
\hline \hline ArticleGrants & $:$ & \\
\hline \hline ArticleContext & $:$ & 130594411 \\
\hline \hline
\end{tabular}




\section{David Secko}

Email: dmsecko@interchange.ubc.ca

Many organisms, including some mammals, fish, and invertebrates, enter suspended animation when their surrounding environment becomes unfavorable. In the nematode Caenorhabditis elegans, severe oxygen deprivation (anoxia) can induce suspended animation, a process that can be fully reversed, even after several days. The mechanisms controlling this process have been unclear, but it has been suggested that gene products may direct the suspension of biological processes, although these gene products have been difficult to identify. In the November 7 Science, Todd G. Nystul and colleagues at the Fred Hutchinson Cancer Research Center report a spindle checkpoint component that is required for suspended animation in C. elegans (Science 2003, 302:1038-1041).

Nystul et al. used RNA interference (RNAi) to test 2445 open reading frames (ORFs) for involvement in anoxia-induced suspended animation, and they identified an ORF that caused C. elegans embryos to lose viability upon exposure to anoxia. The gene was subsequently named san- 1 - for suspended animation 1 - and was observed to be specifically required for anoxia-induced suspended animation, since its loss had no effect on viability under normal conditions (normoxia) or less severe oxygen depletion (hypoxia). The homology of the SAN-1 protein suggested it could be a spindle checkpoint component, and it was subsequently shown to be localized to the poleward faces of chromosomes during metaphase. SAN-1 was also shown to be necessary for nocodazole-induced spindle checkpoint activity, suggesting that spindle checkpoint components were necessary for suspended animation.

The authors then monitored wildtype embryos during anoxia and observed that metaphase increased from $18.2 \%$ in normoxia to $42.9 \%$ in anoxia. In san-l (RNAi) embryos metaphase decreased to $0.7 \%$, and the embryos showed missegregation of chromosomes and aneuploidy, demonstrating that san- 1 was required for an increase in metaphase, "providing a compelling explanation for the anoxia-specific lethality in san-1(RNAi)" embryos.

"We have demonstrated that san- 1 is a component of the spindle checkpoint in C. elegans and that activation of the spindle checkpoint is essential for successful execution of the suspended animation program," conclude the authors.

\section{References}

1. Dephosphorylation of cell cycle-regulated proteins correlates with anoxia-induced suspended animation in Caenorhabditis elegans 
2. Unifying theory of hypoxia tolerance: Molecular/metabolic defense and rescue mechanisms for surviving oxygen lack

3. Science, [http://www.sciencemag.org/]

4. Fred Hutchinson Cancer Research Center, [http://www.fhcrc.org/]

5. Functional genomic analysis of C. elegans chromosome I by systematic RNA interference 